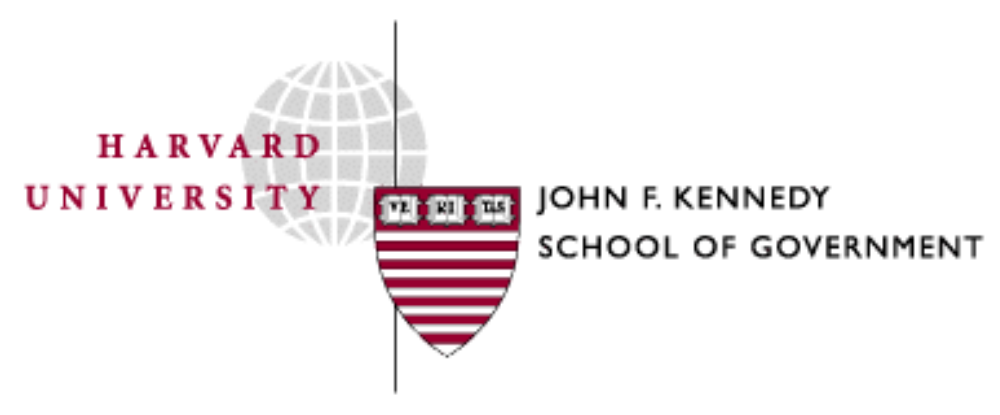

Faculty Research Working Papers Series

Towards an Institutional First Amendment

Frederick Schauer

February 2005

RWP05-020

The views expressed in the KSG Faculty Research Working Paper Series are those of the author(s) and do not necessarily reflect those of the John F. Kennedy School of Government or Harvard University. Copyright belongs to the author(s). Papers may be downloaded for personal use only. 


\title{
TOWARDS AN INSTITUTIONAL FIRST AMENDMENT
}

\author{
Frederick Schauer $^{1}$
}

How shall we subdivide the First Amendment? More specifically, along which lines shall we carve free speech and free press doctrine? In designing the demarcations that are an inevitable part of any area of legal doctrine, shall we locate those demarcations in distinctions among people, or among places, or among forms of behavior, or perhaps among something else? Subdivision is part and parcel of any body of law, and wisely creating the subdivisions is as central to First Amendment doctrine as it is to torts, contracts, agency, antitrust, securities regulation, and of course much, much else.

Traditionally, the First Amendment has been subdivided on the basis of the content of the communication. To put it differently, it has been traditionally supposed, roughly, that the First Amendment's Speech Clause protects speech. The First Amendment does not protect all speech,

${ }^{1}$ Frank Stanton Professor of the First Amendment, John F. Kennedy School of Government, Harvard University. This Article was prepared for the Faegre and Benson Symposium on Law, Information, and Freedom of Expression held at the University of Minnesota Law School on October 22, 2004, in honor of the University of Minnesota Law Library’s Millionth Volume. Research support was generously provided by the Joan Shorenstein Center on the Press, Politics and Public Policy, Harvard University, and I have benefited from Larry Alexander's comments on an earlier draft. I also thank my commentators at the oral presentation-Robert Post, Dale Carpenter, Guy-Uriel Charles, David McGowan, and Miranda McGowan-whose remarks and critique have made the final version far better than it was in its first incarnation. And I offer additional thanks to Carpenter for persuading me to omit the word "prolegomenon" from the title of this Article and from anything else I may ever write. 
or even most speech, but the speech that it does protect is protected as speech, with relatively little regard for the identity of the speaker or the institutional environment in which the speech occurs. Consequently, the type of speech involved not only distinguishes what the First Amendment covers from what it ignores, but plays the primary role in determining, within the universe of covered speech, just how much protection is available, and which tests and doctrines shall be applied. ${ }^{2}$

First Amendment doctrine is of course vastly more complex than this, and the previous paragraph is an egregious oversimplification. Still, something of importance is captured in the way existing First Amendment doctrine renders the Press Clause redundant and thus irrelevant, with the institutional press being treated simply as another speaker. ${ }^{3}$ So too with the Supreme Court's reluctance, save for the exception of broadcasting, ${ }^{4}$ to draw distinctions among different

${ }^{2}$ The sentence in the text presupposes the distinction between coverage and protection that I explain and defend in Frederick Schauer, The Boundaries of the First Amendment: A Preliminary Exploration of Constitutional Salience, 117 HARV. L. REV. 1765, 1769-74 (2004). See also FredericK SCHAUER, FreE SPEECH: A PhILOSOPHICAL ENQUIRY 89-92, 134-35 (1982); Frederick Schauer, Can Rights Be Abused?, 31 PHIL. Q. 225 (1981); Frederick Schauer, Categories and the First Amendment: A Play in Three Acts, 34 VAND. L. REV. 265 (1981); Frederick Schauer, Codifying the First Amendment: New York v. Ferber, 1982 SuP. CT. REV. 285.

${ }^{3}$ First Nat'l Bank of Boston v. Bellotti, 435 U.S. 765, 795 (1978) (Burger, J., concurring); Branzburg v. Hayes, 408 U.S. 665, 704-05 (1972); Lovell v. Griffin, 303 U.S. 444, 452 (1938). The literature on the question whether the Press Clause should be treated as having independent importance is huge. See, e.g., David Anderson, The Origins of the Press Clause, 30 UCLA L. REV. 455 (1983); C. Edwin Baker, Press Rights and Government Power to Structure the Press, 34 U. Miami L. ReV. 838 (1980); David Lange, The Speech and Press Clauses, 23 UCLA L. REV. 77 (1975); Anthony Lewis, A Preferred Position for Journalism?, 7 HofSTRA L. REV. 595 (1979); Melville Nimmer, Is Freedom of the Press a Redundancy: What Does It Add to Freedom of Speech?, 26 Hastings L.J. 639 (1975); Steven W. Shiffrin, Defamatory Non-Media Speech and First Amendment Methodology, 25 UCLA L. REV. 915, 934-35 (1978); Potter Stewart, “Or of the Press”, 26 Hastings L.J. 631 (1975); William W. Van Alstyne, The Hazards to the Press of Claiming a "Preferred Position", 28 HASTINGS L.J. 761 (1977).

${ }^{4}$ FCC v. Pacifica Foundation, 438 U.S. 726 (1978); Red Lion Broadcasting Co. v. FCC, 395 U.S. 367 (1969). 
media, ${ }^{5}$ or with the Court's inclination to treat all government speech as functionally equivalent, without regard to whether the government is speaking as an employer, ${ }^{6}$ an arts funder, ${ }^{7}$ a medical provider, ${ }^{8}$ or a library. ${ }^{9}$

For several decades now, First Amendment doctrine’s eagerness to locate the important lines of protection along the dimension of speech (or expression, or communication, or information ${ }^{10}$ ) has been subject to harsh criticism. For Edwin Baker, locating the values of personal liberty only in speech or communication makes no sense, and he therefore has urged an understanding of the First Amendment that replaces the speech/conduct distinction with the distinction between liberty and non-liberty. ${ }^{11}$ So too with Ronald Coase’s challenge to a First Amendment that treats communicative liberty differently from economic liberty. ${ }^{12}$ Catharine

${ }^{5}$ One good example is the use of the same understanding and definition of "obscenity" across media as diverse as books, magazines, telephone, cable television, and drive-in movie theaters. See, e.g., Ashcroft v. American Civil Liberties Union, 535 U.S. 564 (2002); Playboy Entertainment Group, Inc. v. United States, 529 U.S. 803 (2000); Sable Communications v. FCC, 492 U.S. 115 (1989); Erznoznik v. Jacksonville, 422 U.S. 205 (1975).

${ }^{6}$ Connick v. Myers, 461 U.S. 138 (1983).

${ }^{7}$ Nat'l Endowment for the Arts v. Finley, 524 U.S. 569 (1998).

${ }^{8}$ Rust v. Sullivan, 500 U.S. 173 (1991).

${ }^{9}$ United States v. Am. Library Ass’n, 539 U.S. 194 (2003).

${ }^{10}$ Although "freedom of expression" is the most common quasi-synonym for "freedom of speech," and although "freedom of expression" is the phrase found in, for example, the relevant provisions of the Canadian Charter of Rights and Freedoms (Section 2), and the European Convention on Human Rights (Article 10), it should become clear that substituting words like "expression" or "communication" for the word "speech" will change neither the nature of the problem nor the approach I urge here.

${ }^{11}$ C. Edwin BaKer, Human Liberty And Freedom of Speech (1989); C. Edwin Baker, Harm, Liberty, and Free Speech, 70 S. CAL. L. REV. 979 (1997); C. Edwin Baker, Scope of the First Amendment Freedom of Speech, 25 UCLA L.. REV. 964 (1978).

${ }^{12}$ R.H. Coase, The Market for Goods and the Market for Ideas, 64 AM. ECON. REV. 384 (1974). See also Aaron Director, The Parity of the Economic Market Place, 7 J.L. \& Econ. 1 (1964). 
MacKinnon has objected to treating the consequences of speech acts as meaningfully different from the consequences of other sorts of acts. ${ }^{13}$ Robert Post has proposed replacing "speech" with “democracy” as the basic unit of First Amendment analysis. ${ }^{14}$ Larry Alexander has argued that the effects caused by communicative acts are not different, in any doctrinally or theoretically usable way, from the effects caused by the full range of human behavior. ${ }^{15}$ And for some years I have been questioning the very underpinnings of the speech/action distinction, a distinction upon which so much of First Amendment doctrine rests. ${ }^{16}$

What all of these challenges to the category of "speech" share is a willingness to question a doctrinal structure that treats the distinction between speech and conduct as important. As a result, these challenges routinely express either a consequent willingness to expand to category of First Amendment coverage to include those activities that appear functionally equivalent to speech from a particular theoretical perspective, and/or a parallel willingness to contract the category of coverage to exclude those forms of speech ill-serving a particular theoretical justification for the First Amendment. Yet whether the goal is expansion, contraction, or both, what most of these efforts have in common is a willingness to question whether the category of "speech" is a useful unit of analysis. ${ }^{17}$ Oddly, however, those of us who have questioned the viability of “speech" as the major component of First Amendment understanding have been

${ }^{13}$ CATHARINE A. MACKINNON, ONLY WORDS (1993).

${ }^{14}$ Robert Post, Recuperating First Amendment Doctrine, 47 STAN. L. REV. 1249 (1995).

${ }^{15}$ LARry AleXANDER, Is Freedom OF SPEECH A Human Right? (Forthcoming 2005); Larry A. Alexander, Trouble on Track Two: Incidental Regulations of Speech and Free Speech Theory, 44 HASTINGS L.J. 921 (1993).

${ }^{16}$ Schauer, Free Speech: A Philosophical EnQuiry, supra note 2; Frederick Schauer, Must Speech Be Special?, 78 Nw. U. L. REV. 1284 (1983).

${ }^{17}$ On the "traditional" review that "speech as such" is indeed the primary and appropriate unit of analysis, see Glickman v. Wileman Brothers \& Elliott, Inc., 521 U.S. 457, 478 (1997) (Souter, J., dissenting). 
reluctant to treat the existing but contingent institutional elements of our collective life as important markers along which we might cleave the First Amendment-both in its initial coverage and in its various categories of protection. Much of this reluctance stems from a view about the functions and comparative advantage of the courts. If courts are thought to have little ability to fathom the changeable and empirical foundations of our institutional lives, then there is an extraordinarily strong temptation to draw doctrinal lines on the basis of, to use Ronald Dworkin’s terminology, "principle” rather than "policy."18

Yet however strong this temptation towards institutional blindness, there are good reasons to resist it. As documented and theorized by people such as Niklas Luhmann, advanced societies are experiencing a growing institutional self-reproduction and consequent institutional differentiation. ${ }^{19}$ And as the lines of that institutional differentiation become more and more clear, the argument that courts should ignore them becomes commensurately weaker. Moreover, if we can trust our courts to determine, for example, the fundamental nature of the game of golf ${ }^{20}$ or the status of knowledge about tire failure as a recognized area of expertise,${ }^{21}$ we might also trust them to recognize the difference between the institutional press and the lone pamphleteer, between the Internet and an adult theater, between libraries and medical clinics, and between the National Endowment for the Arts and the National Institutes of Health. In all of these cases there may at times be difficult lines to draw between institutions, but drawing those lines becomes

\footnotetext{
${ }^{18}$ RONALD DWORKIN, LAW’s EMPIRE (1986); RONALD DWORKIN, TAKING RIGHTS SERIOUSLY (1978).

${ }^{19}$ Niklas Luhmann, The Differentiation of Society (1982); Niklas Luhmann, A General Theory of Organized Social Systems, in EUROPEAN CONTRIBUTIONS TO ORGANIZATION THEORY 96 (Geert Hofstede \& M. Sami Kassem eds., 1976).

${ }^{20}$ PGA Tour, Inc. v. Martin, 532 U.S. 661 (2000), amusingly criticized in Frederick Schauer, The Dilemma of Ignorance: PGA Tour, Inc. v. Casey Martin, 2001 SuP. CT. REV. 267.

${ }^{21}$ Kumho Tire Co., Ltd. v. Carmichael, 526 U.S. 137 (1999).
} 
easier to the extent that the lines, which may cut across the distinction between speech and action, follow existing lines of institutional differentiation. Carving First Amendment doctrine across rather than along the distinction between speech and action may yield a First Amendment with less coherence as a matter of abstract principle, but may also give us a First Amendment with greater ability to deal with the genuine issues of institutional autonomy that lie at the heart of the multiple but overlapping background justifications for the idea of freedom of speech.

\section{I. $\quad$ The Doctrine}

Described in the most simplistic terms, the constitutional right to freedom of speech is about the (negative ${ }^{22}$ ) liberty of certain actors to engage in particular forms of behavior. And in equally simplistic terms, the existing doctrine tends to focus on the form of the behavior and not on the identity of the actors. Thus, certain behaviors ${ }^{23}$ receive protection regardless of the

\footnotetext{
${ }^{22}$ As Professor BeVier discusses in her contribution to this Symposium, there are important disputes about the extent to which the First Amendment should be understood in primarily negative and government-limiting terms, as the doctrine largely reflects and as she and others support, e.g., Lucas A. Powe, Scholarship and Markets, 56 GEO. WASH. L. REV. 172 (1987), or whether instead the doctrine should permit or even require various positive efforts by government to enhance the First Amendment environment, as other scholars have argued, e.g., OWen Fiss, The Irony of Free Speech (1996); Cass Sunstein, Democracy and THE PROBlem of FreE SPEeCH (1993). This is an important debate, but it is not my debate here, and my arguments in favor of a more institutionally aware First Amendment doctrine are compatible with either positive or negative views about the basic substance of the constitutional right to freedom of speech.

${ }^{23}$ Everything I say here is compatible with the relevant behavior being the behavior of the government rather than the behavior of the "speaker." So if government actions reflecting certain disfavored motives trigger the First Amendment, see Larry A. Alexander, Low Value Speech, 83 Nw. U. L. Rev. 549 (1989); Elena Kagan, Private Speech, Public Purpose: The Role of Government Motive in First Amendment Doctrine, 63 U. CHI. L. REV. 413 (1996); Jed Rubenfeld, The First Amendment's Purpose, 53 STAN. L. REV. 767 (2001); Frederick Schauer, The Aim and the Target in First Amendment Methodology, 83 Nw. U. L. REV. 562 (1989), the question still remains whether the impermissibility of that motive may vary with the identity, character, or status of the agents against whom it is directed, which as a matter of current doctrine it generally may not. See, e.g., Turner Broadcasting Sys., Inc. v. FCC, 512 U.S. 622, 662-64 (1994) (applying analysis of United States v. O’Brien, 391 U.S. 367 (1968), to cable television).
} 
identity of the actor, and government actions that reflect certain disfavored motives are impermissible regardless of the identity of the target.

The doctrine is replete with examples of the agent- and institution-indifference reflected in the previous paragraph. Just a few months after deciding New York Times Co. v. Sullivan, ${ }^{24}$ which dealt with libelous material published in an advertisement in a major national newspaper, the Supreme Court applied the very same rule in Garrison v. Louisiana, ${ }^{25}$ which arose in the context of verbal and unpublished slander by an individual political candidate. When the Supreme Court crystallized (more or less) the test for obscenity in Miller v. California, ${ }^{26}$ it did so in the familiar setting of a mass mailing of adult materials. But having created the test for obscenity in the context of sales of printed materials by mail, the Court has proceeded to apply the same line between the impermissibly obscene and the permissibly sexually explicit to outdoor theaters, ${ }^{27}$ to dial-a-porn telephone services, ${ }^{28}$ to cable and satellite television, ${ }^{29}$ and to the Internet $^{30}$ — with broadcasting $^{31}$ and non-prohibitory zoning of adult establishments ${ }^{32}$ as the only

${ }^{24} 376$ U.S. 254 (1964).

${ }^{25} 379$ U.S. 64 (1964).

${ }^{26} 413$ U.S. 49 (1973)

${ }^{27}$ Erznoznik v. Jacksonville, 422 U.S. 205 (1975).

${ }^{28}$ Sable Communications, Inc. v. FCC, 492 U.S. 115 (1989).

${ }^{29}$ United States v. Playboy Entertainment Group, Inc., 529 U.S. 803 (2000); Denver Area Educational Telecomms. Consortium v. FCC, 518 U.S. 727 (1996).

${ }^{30}$ Reno v. American Civil Liberties Union, 521 U.S. 844 (1997). Much the same can be said about the contrast between Ginsberg v. New York, 390 U.S. 676 (1968), developing the idea of a modified obscenity standard when material was targeted at minors, and the more recent Internetfocused Ashcroft v. American Civil Liberties Union, 124 S. Ct. 2783 (2004), and Ashcroft v. American Civil Liberties Union, 535 U.S. 564 (2002).

${ }^{31}$ FCC v. Pacifica Foundation, 438 U.S. 726 (1978).

${ }^{32}$ City of Los Angeles v. Alameda Books, Inc., 535 U.S. 425 (2002); Young v. American Mini 
significant exceptions. In refusing to create a constitutional privilege for journalists asked to identify their sources, ${ }^{33}$ the Supreme Court relied in part on the inability of the courts to distinguish professional journalists from the huge variety of other individuals and entities who write or speak for public consumption — an argument that persists to this day when made by those who would oppose a journalists' privilege precisely because of the presence of bloggers and others whose claim to such a privilege could not be clearly demarcated. ${ }^{34}$ So too with questions of access: a constitutional right of access to courtrooms is guaranteed to the public and not just to the press, ${ }^{35}$ just as a right of access to prisons and other governmental facilities is denied to reporters and the public alike. ${ }^{36}$ In upholding a filtering requirement for public libraries, ${ }^{37}$ the Court conceptualized the library as, in part, a purchaser of books and therefore as a government deciding what to say. The Court thus placed the library in the same conceptual hopper as the government providers of health care in Rust $v$. Sullivan, ${ }^{38}$ the government employers in Connick v. Myers, ${ }^{39}$ and the government funders of art in National Endowment for

Theatres, Inc., 427 U.S. 50 (1976).

${ }^{33}$ Branzburg v. Hayes, 408 U.S. 665 (1972).

${ }^{34}$ This argument was made explicitly by Eugene Volokh at the Media Law Resource Center annual conference, held in Alexandria, on Virginia, October 1, 2004, and repeated by him in an op-ed column in the New York Times, available at http://www.nytimes.com/004/12/02/opinion/02volokh.html. For Volokh, the position may be part of a more global skepticism about line-drawing. See Eugene Volokh, Crime-Severity and Constitutional Line-Drawing, 90 Va. L. Rev. 1957 (2004).

${ }^{35}$ Press-Enterprise Co. v. Superior Court, 478 U.S. 1 (1986); Press-Enterprise Co. v. Superior Court, 464 U.S. 501 (1984); Richmond Newspapers, Inc. v. Virginia, 448 U.S. 555 (1980).

${ }^{36}$ Houchins v. KQED, Inc., 438 U.S. 1 (1978); Pell v. Procunier, 417 U.S. 817 (1974); Saxbe v. Washington Post Co., 417 U.S. 843 (1974).

${ }^{37}$ United States v. Am. Library Ass’n, Inc., 539 U.S. 194 (2003).

${ }^{38} 500$ U.S. 173 (1991).

${ }^{39} 461$ U.S. 138 (1983). 
the Arts v. Finley. ${ }^{40}$ And the lower court in the same case had conceptualized the library, or at least part of it, as a public forum, ${ }^{41}$ much the same as a parade or a public park. ${ }^{42}$ Thus, when the Supreme Court announced, famously, that “[n]either teachers [n]or students shed their constitutional rights to freedom or expression at the schoolhouse gate,"43 it reaffirmed the general presumption that First Amendment rights do not vary substantially with institutional setting. While occasional exceptions undoubtedly can be found, ${ }^{44}$ it seems a permissible generalization to conclude that First Amendment doctrine has been hesitant to draw lines between or among speakers or between or among communicative institutions, preferring overwhelmingly to demarcate the First Amendment along lines representing different types of speech.

Although the Supreme Court has been reluctant to draw lines among speakers or institutions, that reluctance is certainly not a function of a Court that is squeamish about drawing lines, even with respect to the First Amendment. The Court readily distinguishes incitement from advocacy, ${ }^{45}$ commercial speech from non-commercial speech, ${ }^{46}$ obscenity from indecency, ${ }^{47}$

${ }^{40} 524$ U.S. 569 (1998).

${ }^{41}$ Am. Library Ass’n, Inc. v. United States, 201 F. Supp. 2d 401 (2002).

${ }^{42}$ Capitol Square Review \& Advisory Board v. Pinette, 515 U.S. 753 (1995); Forsyth County v. Nationalist Movement, 505 U.S. 123 (1992).

${ }^{43}$ Tinker v. Des Moines Independent Community School District, 393 U.S. 503 (1969).

${ }^{44}$ Broadcasting is one, for sure, as is the largely differential (and deferential) treatment of speech in the military. See, e.g., United States v. Albertini, 472 U.S. 675 (1985); Greer v. Spock, 424 U.S. 828 (1976).

${ }^{45}$ Brandenburg v. Ohio, 395 U.S. 444 (1969) (per curiam).

${ }^{46}$ Bolger v. Youngs Drug Products Corp., 463 U.S. 60 (1983).

${ }^{47}$ FCC v. Pacifica Foundation, 438 U.S. 726 (1978). 
public interest speech from personal interest speech, ${ }^{48}$ public forums from non-public forums and from "designated" public forums ${ }^{49}$ content-based from content-neutral regulations, ${ }^{50}$ and subjectmatter from viewpoint-based discrimination. ${ }^{51}$ Even though these and numerous other distinctions and demarcations are at times elusive and slippery, the courts have recognized, and properly so, that drawing lines is part of their job ${ }^{52}$ and forms an essential component of the process of adjudication and the larger process of common law development. Only when those lines track institutional differences do the courts appear to have balked. It is thus surprising and anomalous that the same courts that have been quite willing to distinguish the obscene from the indecent and the commercial from the non-commercial have been far less willing to distinguish media from non-media, individual speakers from magazine publishers, adult theaters from the Internet, and so on throughout most of the doctrinal structure of First Amendment decisionmaking.

\section{The Diagnosis}

${ }^{48}$ Dun \& Bradstreet v. Greenmoss Builders, Inc., 472 U.S. 749 (1985); Connick v. Myers, 461 U.S. 138 (1983). For an important critique, see Cynthia L. Estlund, Speech on Matters of Public Concern: The Perils of an Emerging First Amendment Category, 59 GEO. WASH. L. REV. 1 (1990).

${ }^{49}$ See Lillian R. Bevier, Rehabilitating Public Forum Doctrine: In Defense of Categories, 1992 Sup. CT. REV. 79; Daniel A. Farber and John E. Nowak, The Misleading Nature of Public Forum Analysis: Content and Context in First Amendment Adjudication, 70 VA. L. REV. 1219 (1984); Robert C. Post, Between Governance and Management: The History and Theory of the Public Forum, 34 UCLA L. REV. 1713 (1987).

${ }^{50}$ See Susan H. Williams, Content Discrimination and the First Amendment, 139 U. PA. L. REV. 615 (1991).

${ }^{51}$ See Marjorie Heins, Viewpoint Discrimination, 24 HASTINGs Const. L. Q. 99 (1996).

${ }^{52}$ See Louis Henkin, The Supreme Court, 1967 Term, Foreword: On Drawing Lines, 82 HARV. L. REV. 63 (1968). See also LeRoy Fibre Co. v. Chicago, Minneapolis \& St. Paul Ry., 232 U.S. 340, 354 (1914) (Holmes, J., concurring in part) ("The whole law [depends on differences of degree] as soon as it is civilized.”). 
The reluctance of the courts to believe that institutional distinctions can have First Amendment significance and that pre-legal institutional lines might undergird legal doctrinal lines can be attributed to a number of causes, some of which I have suggested in previous writings. ${ }^{53}$ Building on this earlier but more tentative work, I want to explore more fully here what I believe to be the full array of causes for the Supreme Court's continuing hesitancy to take institutions seriously in designing First Amendment doctrine.

The first cause of an institutionally oblivious First Amendment likely resides in the way in which institutional lines do not appear law-like, and appear even less law-like in the constitutional context, where Ronald Dworkin's distinction between policy and principle ${ }^{54}$ looms especially large. However frequently common law courts engage in quasi-empirical policy analysis to make the common law, ${ }^{55}$ such an approach seems more alien to constitutional law, the prototypical "forum of principle." 56 So if judges believe that lines drawn according to legal (and thus non-empirical and non-sociological) categories are more faithful to the judicial, legal, and constitutional enterprises than lines drawn according to the pre-legal categories of the worldand this is the whole point of Holmes's famous story of the Vermont justice of the peace and the $\operatorname{churn}^{57}$ — then we might expect to see an eagerness from our judges to decide in the categories of

${ }^{53}$ In particular, the idea that the legal mind may be hostile to non-legal categories is an idea I discuss in Frederick Schauer, Prediction and Particularity, 78 B.U. L. REV. 773 (1998), and then apply, more superficially than here, in Frederick Schauer, The Supreme Court, 1997 Term: Comment: Principles, Institutions, and the First Amendment, 112 HARV. L. REV. 84 (1998).

${ }^{54}$ See DWORKIN, supra note 15.

${ }^{55}$ See Melvin A. Eisenberg, The NAture of the Common LAW (1988).

${ }^{56}$ Ronald Dworkin, The Forum of Principle, 56 N.Y.U. L. REV. 469 (1981).

${ }^{57}$ When Holmes mocked the non-legally trained Vermont justice of the peace who tried to find the relevant law for the non-return of a borrowed butter churn under the heading "churn" rather than under some legal category like "replevin," Oliver Wendell Holmes, The Path of the Law, 1 B.U.L. REV. 457, 474-75 (1897), his point was that legality is largely defined by the extent to which legal constructs rather than pre-legal categories of the world are primarily relevant to legal decision-making. For present purposes, the important point is the contrast between the influence 
the law rather than the categories of our pre-legal and extra-legal existence. What distinguishes categories like viewpoint discrimination, content regulation, public forum, and prior restraint from categories like universities, libraries, elections, and the press is that the former exist in the First Amendment but the latter exist in the world. And insofar as many lawyers and judges, following Holmes, sense more than a bit of bad odor when we design doctrine around the contingent and variable structures of the world rather than around the allegedly more stable (and, for judges, certainly more controllable) categories of law, we can explain at least part of the resistance to shaping the First Amendment around societal institutions. For too many judges, it seems, delineating the contours of such institutions would look like a rather un-judicial enterprise.

Relatedly, some of this reluctance to move towards an institutionally specific First Amendment is explained by the fact that understanding non-legal institutions, describing them, and then designing doctrine around them would take appellate courts into empirical realms in which they are uncomfortable and as to which appellate records are likely to be particularly deficient. Especially for a Supreme Court that has been frank about its lack of knowledge of new and rapidly changing technologies such as the Internet and other aspects of modern communications, ${ }^{58}$ carving doctrine along lines that the doctrine-creator may only dimly

this conception of the law still exerts and the reality of modern law itself, which includes numerous areas of law_-securities regulation, for example, and perhaps even admiralty — that are tailored to the pre-legal and extra-legal categories of the world rather than to doctrinal abstractions. See Schauer, Prediction and Particularity, supra note 53; cf. Gerald Leonard, Comment on Frederick Schauer's Prediction and Particularity, 78 B.U. L. REV. 931 (1998). For a recent and well-known example of the same debate, compare Frank H. Easterbrook, Cyberspace and the Law of the Horse, 1996 U. Chi. Legal F. 207, 208 (arguing that there is no more a "law of cyberspace" than there is a "law of the horse"), with Lawrence Lessig, Comment, The Law of the Horse: What Cyberlaw Might Teach, 113 Harv. L. Rev. 501 (1999) (arguing for the existence and desirability of cyber-specific legal principles).

${ }^{58}$ See especially Reno v. ACLU, 521 U.S. 844 (1997), and Denver Area Educational Telecommunications Consortium, Inc. v. FCC, 518 U.S. 727 (1996) 
understand appears to invite a host of problems. Some of these problems may involve simply getting things wrong, but more may involve the question of change: How can courts, with their special mission of stability for stability’s sake, ${ }^{59}$ respond to changing institutions and changing technology and overcome what H.L.A. Hart famously referred to as the "handicaps" of the "human predicament”_ “our relative ignorance of fact” and "our relative indeterminacy of aim”? ${ }^{60}$

Yet although we should not ignore this dilemma of ignorance, in which courts both need and yet do not possess the empirical information with which they must decide cases and make doctrine, this is not an obstacle that by and large has troubled the courts, however much it might plausibly be argued that it should. As long as the Supreme Court is willing to enter into empirical and institutional inquiry in areas in which neither the briefs nor the record below yield the requisite information — as long as the Court with its own knowledge and its own research is willing to opine about the fundamental nature of golf, ${ }^{61}$ the frequency of flawed ballots, ${ }^{62}$ and the behavior of the press in the face of potential legal liability, ${ }^{63}$ for example-there should be little special concern if that same Court is willing to opine about the differences (or not) between journalists and bloggers, between speeches and magazines, between parks and bulletin boards, or

${ }^{59}$ To say that not everyone accepts this characterization is a wild understatement, but at least some of us do. See Larry Alexander \& Frederick Schauer, On Extrajudicial Constitutional Interpretation, 110 HARV. L. REV. 1359 (1997). See also Larry Alexander \& Frederick Schauer, Defending Judicial Supremacy: A Reply, 17 Const. Comm. 455 (2000).

${ }^{60}$ H.L.A. HART, THE CONCEPT OF LAW 128 (2d ed. 1994).

${ }^{61}$ PGA Tour, Inc. v. Martin, 532 U.S. 661 (2001).

${ }^{62}$ Bush v. Gore, 531 U.S. 98 (2000).

${ }^{63}$ New York Times v. Sullivan, 376 U.S. 254 (1964). The entire Sullivan rule is based on the irreducibly empirical and contingent premise that publishers at risk of legal liability will refrain from engaging in "uninhibited," "wide-open," and "robust" reportage-a premise that may be more contestable than the Court believed in Sullivan. See Frederick Schauer, Uncoupling Free Speech, 92 COLUM. L. REV. 1321 (1992). 
between universities and, say, for-profit trade schools. ${ }^{64}$

This resistance to institution-specific doctrine should perhaps cause little surprise in light of the modern history of First Amendment development and debates. From the time that Justices Black, Douglas, Harlan, and Frankfurter debated the merits of "absolutes" and "balancing,"65 cheered on from one sideline or the other by Alexander Meiklejohn ${ }^{66}$ and Wallace Mendelson, ${ }^{67}$ there have been few greater terms of opprobrium in First Amendment rhetoric than "ad hoc.” Perhaps because so many prominent First Amendment litigants have been bad people with dangerous things to say ${ }^{68}$ and perhaps because so many others have at the very least existed on the fringes of social respectability, ${ }^{69}$ there has always been a worry that an ad hoc First

${ }^{64}$ Implicit in this statement is the view that an institutional account of the First Amendment might yield more of a genuine privilege (that is, immunity from an otherwise applicable requirement, analogous to a reporter's privilege) of academic freedom than now exists in current doctrine. On the basic foundations for the claim to such a privilege, see Robert Post, The Structure of Academic Freedom (unpublished manuscript presented at the Harvard Law School Public Law Workshop on October 7, 2004). As a matter of existing doctrine, the privilege can be argued to exist, see Board of Regents of Univ. of Cal. v. Bakke, 438 U.S. 265, 312 (Powell, J., concurring); cf. Grutter v. Bollinger, 539 U.S. 306, 324-25 (2003), but it remains vanishingly small. Univ. of Pennsylvania v. EEOC, 493 U.S. 182 (1989).

${ }^{65}$ The best overview and analysis of the debates is Laurent Frantz, The First Amendment in the Balance, 71 YALE L.J. 1424 (1962). See also Laurent Frantz, Is the First Amendment Law?: A Reply to Professor Mendelson, 51 CAL. L. ReV. 729 (1963).

${ }^{66}$ Alexander Meiklejohn, The First Amendment Is An Absolute, 1961 Sup. CT. REV. 245.

${ }^{67}$ Wallace Mendelson, The First Amendment and the Judicial Process: A Reply to Mr. Frantz, 17 VA. L. REV. 479 (1964).

${ }^{68}$ Clarence Brandenburg in Brandenburg v. Ohio, 395 U.S. 444 (1969), was a local Ku Klux Klan leader, cross-burners have made frequent appearances in the cases, see Virginia v. Black, $123 \mathrm{~S}$. Ct. 1536 (2003); R.A.V. v. St. Paul, 505 U.S. 377 (1992), and of course there is Frank Collin and the American Nazi Party, Collin v. Smith, 578 F.2d 1197 (7th Cir. 1978); Nat'l Socialist Party of Am. v. Village of Skokie, 373 N.E. 21 (Ill. 1977), aff'd, 432 U.S. 43 (1977) (per curiam).

${ }^{69}$ Indeed, much of the history of the modern First Amendment has been created by the Jehovah's Witnesses, a group that Zechariah Chafee once characterized as having "great religious zeal and astonishing powers of annoyance.” ZeChARIAH CHAFEE, JR., FreE SPEECH IN THE UNITED StATES 399 (1948). And even such First Amendment icons as the narcissistic Lenny Bruce were 
Amendment would be especially vulnerable to excess constriction by judges and juries too concerned with the moral or social undesirability of those who were carrying the First Amendment claim. Some of this worry, that making the First Amendment too person- (or group-) specific would weaken the First Amendment, has seemed to leak, perhaps appropriately and perhaps inappropriately, into the question of institutional specificity as well.

Finally, and perhaps most importantly, some of the resistance to taking institutions seriously in the design of First Amendment doctrine may be based on the mistaken belief that the First Amendment exists, at moral bedrock, as an individual right. If this were so, it would indeed be odd were the contours of such a right to vary significantly with the ever-changing nature of fluid social, economic, and political institutions. But it is hardly apparent that the First Amendment is centrally about individual rights in any strong sense. Not only does the First Amendment frequently and properly provide protection to other-regarding and harmful acts, a surprising feature for a truly individual right, ${ }^{70}$ but a large number of the widely accepted justifications for freedom of speech are about the social and not individual value of granting to individuals an instrumental right to freedom of speech. because it promotes the values of the marketplace of ideas as a facilitator of the search for truth, ${ }^{72}$ almost as infuriating to their friends as to their enemies. See Frederick Schauer, The Heroes of the First Amendment, 101 MicH. L. REV. 2118 (2003).

${ }^{70}$ See Frederick Schauer, Free Speech:A Philosophical Enquiry, supra note 2, at 2-14; Schauer, Uncoupling Free Speech, supra note 63.

${ }^{71}$ Notably, understanding the First Amendment in non-individual terms is not inconsistent with thinking that the best way to protect the social value is by granting individuals the rightstanding, if you will— to enforce it. Thus, we might grant rights to The Washington Post not because it has rights in the deepest sense, but because granting it legal or constitutional rights serves a collective interest in avoiding the bad government that comes from a government unchecked by press aggressiveness. And we might grant rights to dissenters again not because the dissenters have fundamental rights, but because giving them legal or constitutional or political rights to dissent might serve a larger social interest in minimizing the number of bad policy choices and maximizing the number of good ones. See Cass R. SunsteIn, WhY SOCIETIES NEED DisSENT (2003).

${ }^{72}$ Which I do not. See Schauer, FreE SPEECH: A PhilosophicAl ENQUiRY, supra note 2, at 15- 
or the values of checking government abuses,$^{73}$ or even the values of facilitating democratic deliberation among the populace, ${ }^{74}$ for example, then we perceive a right to freedom of speech that lies not at moral bedrock, but is empirically contingent and instrumental to something deeper. And if the right to freedom of speech is contingent, empirical, and instrumental, then it would be far less odd to think of it in contingent empirical institutional terms than if it is understood simply and foundationally to embody—as do the Eighth Amendment and the Free Exercise Clause, for example—an irreducible human right. ${ }^{75}$

III The Problem

34. See also Stanley Ingber, The Marketplace of Ideas: A Legitimizing Myth, 1984 DukE L.J. 1. ${ }^{73}$ Vincent Blasi, The Checking Value in First Amendment Theory, 1977 Am. B. Found. REs. J. 521.

${ }^{74} \mathrm{As}$ stated in the accompanying text, the idea is a vision of democratic deliberation, perhaps most associated with Alexander Meiklejohn, in which the reference point is the process of collective decision-making. AleXander Meiklejohn, Political Freedom (1960); Alexander Meiklejohn, Free Speech and Its Relation to Self-Government (1948). But to the extent that democratic deliberation is seen instead, or in addition, in terms of the participatory interests and consequent self-governance of individual citizens, see Robert Post, The Constitutional Concept of Public Discourse: Outrageous Opinion, Democratic Deliberation, and Hustler Magazine v. Falwell, 103 HARV. L. Rev. 603 (1990); Robert Post, Meiklejohn's Mistake: Individual Autonomy and the Reform of Public Discourse, 64 U. CoLo. L. REV. 1109 (1993), then this particular argument in the text is, pro tanto, less applicable.

${ }^{75}$ Ronald Dworkin argues, plausibly, that freedom of speech is an individual right (a principle) in a strong sense, but that freedom of the press is a policy because of its empirical and instrumental character. Ronald Dworkin, The Farber Case: Reporters and Informers, in A MATTER OF PRINCIPLE 373 (1985). Implicit in what I say here is that much of freedom of speech as well as freedom of the press has this character, but that if we accept (as I do and Dworkin does not) that courts have important roles to play in enforcing second order policies against first order political preferences, see Frederick Schauer, Judicial Supremacy and the Modest Constitution, 92 CALIF. L. REV. 1045 (2004), then the instrumental character of either right is no bar to its judicial enforcement, and no bar to the judiciary doing the best it can to make the best second-order policy decisions it can. This will be more empirical and variable than Dworkin would prefer, but then the large question becomes whether constitutional courts have important roles to serve beyond the protection of rights in the strong sense, a proposition to which I subscribe but to which Dworkin, at times, apparently does not. 
So what? That the First Amendment remains hostile to institutional demarcations cannot be taken as an indication of a problem unless we can identify existing or potential outcomes that would be better under a different approach. Put differently, moving towards an institutional First Amendment only makes sense if existing doctrine too often treats settings, institutions and contexts similarly when, from the perspective of some (or any) account of what the First Amendment, they are substantially and relevantly different.

I do not want to suggest that any act of treating unalikes alike is evidence of a problem. Treating unalikes alike is simply what rules do, ${ }^{76}$ and at the heart of a strongly rule-based First Amendment ${ }^{77}$ is the necessary and desirable suppression of factors and distinctions that would in other contexts be highly politically, morally, or otherwise relevant. To treat cross-burners, Nazis, abortion clinic protesters, Vietnam War civil disobedients, civil rights demonstrators, celebrants of sexual violence, and authors of serious works about sexuality as functionally equivalent, for example, is hardly a moral imperative. Yet such conflation of the morally and politically divergent in the service of avoiding content-based or viewpoint-based distinctions explains much of the unalterable core of the First Amendment. Indeed, much the same argument can be made about the many of the other morally and politically relevant distinctions_-between the truth and falsity of political and moral (and many factual) propositions, most obviously — that First Amendment doctrine properly renders immaterial.

Nevertheless, there may be a point at which First Amendment doctrine’s institutional agnosticism has a highly distorting effect. When the Supreme Court's unwillingness to delineate

\footnotetext{
${ }^{76}$ And treating unalikes alike is also, slightly more controversially, what the concept of equality does. On treating likes alike and unalike, see FrEDERICK SCHAUER, ProfiLEs, Probabilities, AND STEREOTYPES 199-223 (2003); Kenneth I. Winston, On Treating Like Cases Alike, 62 CALIF. L. REV.1 (1974).

${ }^{77}$ See Frederick Schauer, The Second-Best First Amendment, 31 WM. \& MARY L. REV. 1 (1989).
} 
the boundaries of the institutional press produces fewer press rights-in particular rights of access and rights to withhold confidentially obtained information-than exist in many countries with a far more constricted view of freedom of speech and freedom of the press in general, ${ }^{78}$ there is some indication of a problem. When we are compelled to treat mass distribution of detailed instructions for causing harm ${ }^{79}$ in the same way that we treat an individual speaking to a live audience, we face a different kind of problem: too much protection rather than too little. And when First Amendment doctrine insists that the Internet, cable television, telephone, newspapers, magazines, and books are for many purposes indistinguishable, serious questions arise as to whether courts have overlooked important historical, structural, economic, and cultural differences among the various channels and institutions of communication.

Part of the reason for concern is that with respect to some topics the degree of protection may turn out to be too much, and that is not an unreasonable view about what would happen were we to apply the fiercely speech-protective Brandenburg v. Ohio ${ }^{80}$ test to bomb-making and contract-killing instructions. But the issue is not just the question of too much or too little. Rather, another and distinct part of the reason for concern is that the dynamics of the First Amendment may turn out to produce too little protection for what is most important if we continue to insist on drawing too few lines between culturally significant institutional categories.

\footnotetext{
${ }^{78}$ See Frederick Schauer, The Exceptional First Amendment, in AMERICAN EXCEPTIONALISM AND HuMAN RigHTS (Michael Ignatieff, ed., forthcoming 2005).

${ }^{79}$ The most prominent reported case is Rice v. Paladin Enterprises, 128 F.3d 233 (4th Cir. 1997), dealing with a manual for contract killing ("Hit Man”), but the most salient questions are about Internet-distributed instructions for making and using weapons, or for engaging in various terrorist acts. See generally David A. Anderson, Incitement and Tort Law, 37 WAKE FOREST L. REV. 957 (2002); Isaac Molnar, Note, Resurrecting the Bad Tendency Test to Combat Instructional Speech: Militias Beware, 59 OHIO ST. L. J. 1333 (1998); Bryan J. Yeazel, Note, Bomb-Making Manuals on the Internet: Maneuvering a Solution Through First Amendment Jurisprudence, 16 Notre Dame J. L. Ethics \& Pub. Policy 279 (2002).

${ }^{80} 395$ U.S. 444 (1969) (per curiam).
} 
Here the basic idea is that of dilution, and the principle has its crispest articulation in the case law in Justice Powell's opinion in Ohralikv. State Bar of Ohio. ${ }^{81}$ In reacting to the common suggestion that commercial speech ought to be treated in more or less the same way as noncommercial speech, ${ }^{82}$ Justice Powell worried about what we might call the equilibrium point of such equivalent treatment. It was simply not plausible, he argued, to expect potentially false, misleading, coercive, and dangerous commercial advertising to be evaluated against something like the Brandenburg standard. If advertising were to be evaluated in the same way as ideological advocacy, it would be unlikely that commercial advertising would get Brandenburglevel protection and far more likely that Clarence Brandenburg and others would wind up with Virginia Pharmacy ${ }^{83}$ and Central Hudson ${ }^{84}$ levels of protection-an equivalence which would have grave negative effects on the core principles of the First Amendment. ${ }^{85}$

Other isues in contemporary First Amendment doctrine create similar risks of institutional “compression,” and thus of leveling down rather than leveling up. A Supreme Court

${ }^{81} 436$ U.S. 447 (1978).

${ }^{82}$ See 44 Liquormart, Inc. v. Rhode Island, 517 U.S. 484, 537 (1996) (Thomas, J., concurring and concurring in the judgment); City of Cincinnati v. Discovery Network, 507 U.S. 410 (1993) (Stevens, J.); Daniel A. Farber, Commercial Speech and First Amendment Theory, 74 Nw. U. L. REV. 372 (1979); Alex Kozinski and Stuart Banner, The Anti-History and Pre-History of Commercial Speech, 71 TEXAS L. REV. 747 (1993); Martin H. Redish, The First Amendment in the Marketplace: Commercial Speech and the Values of Free Exprssion, 39 GEO. WASH. L. REV. 429 (1971). See also Kathleen M. Sullivan, Cheap Spirits, Cigarettes, and Free Speech: The Implications of 44 Liquormart, 1996 SuP. CT. REV. 123, 160 (1996) (predicting a Supreme Court that is likely to move commercial speech "somewhat closer to the core of the First Amendment”).

${ }^{83}$ Virginia State Board of Pharmacy v. Virginia Citizens Consumer Council, 425 U.S. 748 (1976).

${ }^{84}$ Central Hudson Gas \& Elec. Corp. v. Public Service Comm’n of New York, 447 U.S. 557 (1980).

${ }^{85}$ For my own full development of what was originally Justice Powell's idea, see Frederick Schauer, Commercial Speech and the Architecture of the First Amendment, 56 U. Cinc. L. REV. 1181 (1988). 
unwilling to distinguish among the lone pamphleteer, the blogger, and the full-time reporter for the New York Times is far less likely to grant special privileges to pamphleteers and bloggers than it is, as it has, to grant privileges to no one. A Court that believes it must apply the same definition or standard of regulability on grounds of offensive content to both broadcast television and Bob’s XXXX Adult Bookstore and Peepshow is, in reality, much more likely to allow less for Bob than it is to permit virtually everything for CBS during prime time or during halftime of the Super Bowl. And a Court that must allow Brandenburg v. Ohio ${ }^{86}$ and Hess v. Indiana ${ }^{87}$ to determine which forms of bomb-making instructions on the Internet will be protected is a Court that might be especially susceptible to pressure to cut back on Brandenburg's protection not only for people like Brandenburg, but also for people engaging in individual advocacy but whose moral worth and substantive message is considerable greater than was Brandenburg's.

All of this suggests that there may indeed be a problem in need of a solution. Notwithstanding all of the empirical contingency and sociological messiness of institutional demarcation, if the persistent unwillingness to take institutions seriously produces both distorted doctrine and under-protection precisely where it is most dangerous, then closer attention to institutional lines seems pressing. While my goal on this occasion is only to suggest a relatively new avenue of inquiry, rather than to prescribe specific tests and specific lines, it may be worthwhile to look at what such an approach might yield.

\section{An Institutional Account of the First Amendment}

I do not want to make my inquiry look more foundational than it is. At least here, my

\footnotetext{
${ }^{86} 395$ U.S. 444 (1969) (per curiam).

${ }^{87} 414$ U.S. 105 (1973). In holding that a call for violent action- “tak[ing] the fucking street""later" in the day was not sufficiently imminent to support punishment of the speaker, Hess represents the Supreme Court's clearest (and only) articulation of the "imminence" aspect of the Brandenburg test.
} 
concern is not with identifying those deep themes in constitutional and democratic theory that would tell us where to locate serious free speech claims and how to distinguish them from the comparatively unimportant. ${ }^{88}$ Rather, I want to suggest that a certain number of existing social institutions in general, even if not in every particular, serve functions that the First Amendment deems especially important, ${ }^{89}$ or may carry risks that the First Amendment recognizes as especially dangerous. To the extent that this is so, a recast First Amendment could more consciously treat these institutions in rule-like fashion, with the institutions serving as under- and over-inclusive, but not spurious, markers of deeper background First Amendment values. Like a speed limit sign that moves the inquiry from dangerous driving to whether the driver was or was not driving in excess of the posted speed, a First Amendment doctrine that embodied the same approach to institutions would analogize certain institutions to rules. An institutional First Amendment would thus move the inquiry away from direct application of the underlying values of the First Amendment to the conduct at issue and towards the mediating determination of

${ }^{88}$ Although egregiously compressed into one sentence, this is in part my "meta” characterization of work such as Robert Post's, see supra note74, which is also concerned with social structure and the identification of special free speech domains. Post's work, however, is far less concerned than I am with the identification of concrete and pre-existing cultural institutions that might in the large serve important free speech functions, and which thus might be deserving of constitutionally guaranteed autonomy as institutions, even when they do not serve the purposes grounding the recognition of their institutional autonomy in the first instance. Like the First Amendment itself, therefore, my approach is categorical. The First Amendment is under- and over-inclusive vis-a-vis the relevant background First Amendment justifications, and thus there should be no barrier in principle to taking this categorical dimension to the next remove. So just as the First Amendment is itself a coarse marker of its background justifications, taking the relevant categories within the First Amendment as coming from existing social institutions far more than from background and thus more likely cross-cutting theoretical justifications is little more than the extension of a fundamental point about the First Amendment itself. Institutions mediate between background theory and particular outcomes, and I want to locate institutions as units of First Amendment analysis insofar as particular institutions, maybe poorly but not spuriously, disproportionately reflect the concerns and limits of the First Amendment.

${ }^{89}$ More accurately, various institutions may reflect one or more of several of the First Amendment's background purposes. The First Amendment is one amendment, and the speech clause is one clause within it, but there is no reason to suppose that that one clause reflects and embodies one and only one deeper value. 
whether the conduct at issue was or was not the conduct of one of these institutions.

Consistent with such an approach, ${ }^{90}$ we might imagine a First Amendment that less grudgingly accepted colleges and universities as appropriate areas for highly (externally) unregulated inquiry, and thus as domains in which the array of privileges in the strict senseacademic freedom as a genuine immunity from certain laws of general application—was constitutionally guaranteed. Much the same might be said about libraries, which are both (relatively) easily identifiable and play a special role in knowledge acquisition. Similar arguments could support an analogous privilege for scientific research, even that scientific research that does not have a home within a university. For all of these institutions, the argument would be that the virtues of special autonomy—special immunity from regulation — would in the large serve important purposes of inquiry and knowledge acquisition, and that those purposes are not only socially valuable, but also have their natural (or at least most comfortable) home within the boundaries of the First Amendment.

For different reasons, as I have suggested above, we might imagine a conceptually similar treatment for the institutional press. Here the justifications might have much less to do with knowledge acquisition and much more with checking government abuse and providing a forum for democratic deliberation, but the structure of the argument is similar. We ${ }^{91}$ first locate

\footnotetext{
${ }^{90}$ And arguably consistent with the Supreme Court's willingness to draw institutional and similar lines within the Fourth Amendment, of which the separate principles for automobiles is one of the more visible and debated. See Craig M. Bradley, The Court's “Two Model” Approach to the Fourth Amendment: Carpe Diem!, 84 J. Crim. L. \& Criminology 429 (1993); Comment, Toward a Functional Fourth Amendment Approach to Automobile Search and Seizure Cases, 43 Ohio St. L.J. 861 (1982).

${ }^{91}$ Obviously the "we" is problematic and contestable, but implicit in the argument here is the premise that courts might be the appropriate vehicles both for determining which values the First Amendment best reflects, and which institutions especially embody and promote those values. This position itself incorporates the premise that anti-majoritarian and (comparatively) politically immune courts are the institutions most capable of protecting second-order values like freedom of speech and freedom of the press from the pressures of first-order policy-making. See Schauer, Judicial Supremacy and the Modest Constitution, supra note 75.
} 
some value that the First Amendment treats, or should treat, as particularly important. Then we investigate whether that value is situated significantly within and thus disproportionately served by some existing social institution whose identity and boundaries are at least moderately identifiable. If so, then we might develop a kind of second-order test. If there is a reporter's privilege, for example, we might ask not whether this exercise of the privilege serves primary First Amendment purposes, but instead simply whether the person claiming the privilege is a reporter. Obviously, defining the category of people who receive the privilege will be based both on the reasons for having the privilege and the reasons for locating it in a particular institution, but the case by case inquiry will largely consist of applying the rule, rather than applying the reasons lying behind the rule directly to individual cases. ${ }^{92}$

We might conjecture that there could be a similar approach to the arts, and indeed just such an approach was urged by Acting Solicitor General Seth Waxman in the National Endowment for the Arts v. Finley. ${ }^{93}$ Faced with the prospects of unrealistically denying to the government the ability to make content-based and viewpoint-based determinations in the expenditures of its money, or in the alternative of unrealistically claiming that the First Amendment was no more relevant to arts funding than it was to a President's decision to dismiss a cabinet officer because of the content and viewpoint of her public speeches, Solicitor General Waxman argued that "there is something unique . . . about the Government funding of the arts

\footnotetext{
${ }^{92}$ This is an understanding of just what a rule is that I develop at length in FREDERICK SCHAUER,

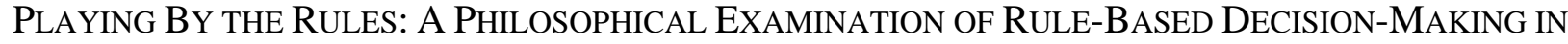
LAW AND IN LIFE (1991). Just as application of a "no driving while talking on a mobile telephone" rule will focus on whether the driver was talking on the telephone and not on whether the driver was driving unsafely or whether the driver was distracted, so too might an institutional approach to the First Amendment develop rules whose application involved questions more focused on membership in the institution than on direct application of the First Amendment's purposes to particular agents and particular controversies.
}

${ }^{93} 524$ U.S. 469 (1998). 
for First Amendment purposes." ${ }^{94}$ It is hard to know with any degree of confidence the extent to which this suggestion has influenced the doctrine regarding arts funding, but Waxman’s recognition that the arts as an institution is an appropriate category of First Amendment analysis is a far cry from thinking that such a category ought to be expunged from legal and First Amendment analysis.

An institutional perspective on the First Amendment would not necessarily serve as a vehicle for more First Amendment protection, even assuming that words like "more" and "less" are particularly helpful in dealing with difficult First Amendment issues. Elections, for example, might be thought of as an institution, and an election-specific account of some aspects of First Amendment doctrine might produce greater immunity in some areas and less than existing immunity in others. ${ }^{95}$ It might be, for example, that the mandates of fairness and non-coercion would allow greater restrictions in the electoral context, but also that the risks of government regulation in its own electoral interests would allow fewer restrictions in the electoral context than might be permitted in other domains.

Much the same might be said about various possibilities for media-specific rules and principles. If First Amendment doctrine were to distinguish the Internet from the telephone in much the same way it now distinguishes broadcasting from print ${ }^{96}$ and broadcasting from cable, ${ }^{97}$

${ }^{94}$ Transcript of Oral Argument, National Endowment for the Arts v. Finley, 1998 WL 156955 at *27 (March 31, 1998). See also Finley, 524 U.S. at 615-16 (Souter, J., dissenting); Amy Sabrin, Thinking About Content: Can It Play an Appropriate Role in Government Funding of the Arts, 102 YALE L.J. 1209 (1993).

${ }^{95}$ See C. Edwin Baker, Campaign Expenditures and Free Speech, 33 HARV. CIV. RTS-CIV. LIB. L. REV. 1 (1998); Frederick Schauer \& Richard H. Pildes, Electoral Exceptionalism and the First Amendment, 77 TeXAs L. REV. 1803 (1999).

${ }^{96}$ Compare Red Lion Broadcasting Co. v. FCC, 395 U.S. 367 (1969), with Miami Herald Pub. Co. v. Tornillo, 418 U.S. 241 (1974). See Lee C. Bollinger, Freedom of the Press and Public Access: Toward a Theory of Partial Regulation of the Mass Media, 75 MicH. L. REV. 1 (1976). 
the change might produce less protection for some media and more for others. For present purposes, however, the point is less about the degree of protection and more about the kinds of institutions, all pre-legal and extra-legal, and all existing in the world without benefit of much constitutional ,legal, democratic, or free speech theory, that might serve as appropriate units of

First Amendment analysis. of First Amendment values. Others might be the loci of a range of dangers which might militate especially striongly for restriction. But whether locations of special protection or special permissiveness of regulation, it seems increasingly implausible to imagine that such institutionally-defined locations should play only a minimal role in the design of First Amndment doctrine..

\section{Conclusion}

My goal here is simple. It is no more than to suggest that we have over the course of

\footnotetext{
${ }^{97}$ United States v. Playboy Entertainment Group, 529 U.S. 803 (2000). Statutes and regulations, of course, draw these kinds of distinctions all the time, just as journalists' shield laws draw the very distinctions the Supreme Court is afraid of drawing, see infra note 101 and accompanying text, and just as various statutes create the kind of religious exemptions from laws of general application that the Supreme Court has often been reluctant to draw. Compare Board of Educ. v. Mergens, 496 U.S. 226 (1990), and Corporation of Presiding Bishop v. Amos, 483 U.S. 327 (1987), with Goldman v. Weinberger, 475 U.S. 503, 534 (1986) (Stevens, J., concurring). Once we recognize that an institutional approach to the First Amendment would do no more than draw the kinds of lines that legislatures and regulatory agencies draw all the time, the inquiry focuses on whether there is something inappropriate about such action when taken by judges as opposed to legislatures. A large literature addresses this problem, see Mitchell Berman, Constitutional Decision Rules, 90 VA. L. REV. 1 (2004), a problem existing against the background of the view that courts should announce principles or declare meaning, leaving it to other bodies to make more detailed implementing rules. But for those of us who believe that the distinction among constitutional meanings, constitutional principles, and constitutional implementing rules is largely illusory, see Daryl J. Levinson, Rights Essentialism and Remedial Equilibration, 99 Colum. L. REV. 857 (1999); David Strauss, The Ubiquity of Prophylactic Rules, 55 U. CHI. L. REV. 190 (1988), the fact that legislatures have for so long done what the Supreme Court finds so difficult to do is less of a knock-down argument than it might be for others. If there is no reason to believe that a legislative definition of what a journalist is, for example, is any better informed than would be a parallel judicial definition, the argument against institutional specificity becomes commensurately even weaker.
} 
eighty-five years of serious First Amendment adjudication ${ }^{98}$ developed a panoply of vague definitions, marginally (at best) useful three- and four-part tests, and slippery and hard to apply categories —all of which together have produced a not-all-that-bad First Amendment terrain. And thus if a moderately satisfactory set of outcomes in the aggregate can tolerate loose definitions, fuzzy lines, and empirical guesswork, then there is no a priori reason to believe that the loose definitions, fuzzy lines, and empirical guesswork involved in focusing First Amendment doctrine on existing social institutions with special First Amendment properties should produce worse results. Just as contract and tort law came to recognize the world of securities transactions as an institutionally specific domain whose institutionally specific properties mandated special rules, ${ }^{99}$ so too might First Amendment doctrine recognize those informational, investigative, and communicative domains whose more-or-less distinctive properties warrant special First Amendment treatment. The Supreme Court in Branzburg v. Hayes ${ }^{100}$ was perhaps right to worry about the lines between journalists and other information gatherers and information disseminators, and contemporary bloggers and others are perhaps right to be worried that such lines would be drawn to their disadvantage. Yet such a pristine approach to potentially messy lines has never characterized either the common law, or constitutional adjudication, or the development of First Amendment doctrine. ${ }^{101}$ And if the law in general and the law of the First

\footnotetext{
${ }^{98}$ This is not to suggest that nothing prior to 1919 mattered to subsequent development, or to suggest that the courts have been the only drivers. See DAvid M. RABbAN, FreE SpeEch In ITS FORGOTTEN YeARs (1997). But for present purposes the crude view that the First Amendment started in 1919 will suffice.

${ }^{99}$ See Schauer, Prediction and Particularity, supra note 53.

${ }^{100} 408$ U.S. 665 (1972).

${ }^{101}$ Indeed, a look at existing journalist "shield" laws reveals that the alleged problem is largely illusory. Some of those laws themselves employ crisp and thus under-and over- inclusive designations, as with Pennsylvania's shield law, limited to those working for a "newspaper of general circulation," or a "press association," or a "radio or television station," or a "magazine of general circulation.” PA. CONS. STAT. ANN. § 5942(a) (West 2004). If a statute can sacrifice accuracy for precision, then there is no reason to believe, except under a view about the capacity of the courts that I do not share, see Frederick Schauer, Opinions as Rules, 62 U. CHI. L. REV. 1455 (1995), that courts in designing doctrine cannot do the very same thing. More commonly,
} 
Amendment in particular can remain as tolerant of fuzzy distinctions, under- and overinclusiveness, sometimes arbitrary lines, and hard-to-apply tests as it has been in the past, then there is no reason to believe in a world of growing institutional differentiation that focusing on institutions qua institutions cannot, and should not, be part of the large arsenal of appropriate First Amendment techniques. I have not here attempted to say very much about what an institutional approach to the First Amendment would look like, and perhaps this Article should be understood as an argument for why the seeming arguments against an institutional approach should be deemed inadequate. But even if I have done nothing more than reverse the burden of proof, that reversal alone may suggest that the case against incorporating institutional realities and demarcations into the First Amendment is far weaker than the Supreme Court and many commentators have traditionally believed.

however, shield laws are written in more general terms, as with Michigan's extension of the privilege to "[a] reporter or other person ... involved in the gathering or preparation of news for broadcast or publication.” Мich. ComP. L. ANN. § 767.5a (West 2004). In such cases, it will be up to the courts to define "gathering," "preparation," "news," "broadcast," and "publication," and thus the courts will be required to determine whether such language applies to the Internet, to bloggers, to lone pamphleteers, and the like. See generally Robert D. Lystad and Malena F. Barzilai, Reporter's Privilege: Legislative and Regulatory Developments, in Media Law Resource Center, Bulletin: White Paper on the Reporter's Privilege 83, 95-101 (2004). If existing statutes are comfortable leaving such determinations to the courts, then allowing courts to address the exact same questions in designing doctrine will not involve the courts in decisions any different from those that they are already compelled to make. 